\title{
Multiple Motivations to Read Young Adult Literature in the Lives of Three African-American Middle School Males
}

\section{Introduction}

Long-time young adult literature advocates (Blasingame, 2007; Lesesne, 2003) and adolescent reading researchers (Ivey \& Johnston, 2013; Smith \& Wilhelm, 2002; Wilhelm, 1997) suggest that young adult literature can motivate young people to read voluntarily, both inside and outside school. We know motivation is important, as motivation theorists and researchers have found that motivation to read is a powerful contributor not only to academic reading achievement but also to the disposition and life-long commitment to reading that provides a range of personal and societal benefits (Guthrie, Coddington, \& Wigfield, 2009; Mazzoni, Gambrell, \& Korkeamaki, 1999).

What's less understood, however, is what readers find motivating in texts written for young adult readers. What is it in young adult texts that motivates readers to read them voluntarily? Which texts motivate which readers? What makes a young adult text "relevant" to a reader? Sciurba (2014-2015) suggests, "educators [and researchers] sometimes overlook students' perspectives on their own powerful experiences with texts" and explains, "We do not know how students connect with texts unless they tell us" (pp. 308-309). Seeking out young readers' voices and perspectives on what young adult literature motivates them to read, and why, we conducted a study of African-American adolescents' motivations to read young adult literature in a voluntary summer reading program. 
For the purposes of our research, we draw on Nilsen and Donelson's (2009) definition of young adult literature: “...anything that readers between the approximate ages of twelve and eighteen choose to read either for leisure reading or to fill school assignments" (p. 3). In this article, we share what young adult literature three male African-American adolescent participants in this study-Tariq, Tyrell, and Tyrone ${ }^{1}$ - chose to read when given opportunities to choose. We also share what they had to say about the literature, about reading, and about themselves as readers. The participants' own words and text choices reveal much about what kind of young adult literature they find relevant, and why, and point to multiple motivations—both intrinsic and extrinsic, personal and social—for reading young adult literature.

After we provide a rationale and context for our summer reading program and describe our research goals, we introduce Tariq, Tyrell, and Tyrone and describe their summer reading experiences and our efforts to better understand their multiple motivations to read young adult literature in the summer reading program.

\section{Reading in the Summer}

\section{Summer Reading Loss}

Unfortunately, many young people do not equate summer with reading. As Cahill, Horvath, McGill-Franzen, and Allington (2013) explain, "For many students, reading is seen only as a school-based activity...as an assignment or chore, rather than a pleasurable, leisure activity" (p. 3). But summer reading is a practice necessary for stemming summer reading loss—a "real issue that affects student 
preparedness for the next grade level and widens the achievement gap between students of different socioeconomic backgrounds" (Cahill et al., 2013, p. 2).

Reading experts Allington and McGill-Franzen (2013) define summerreading loss as "that backsliding in reading development that can occur during the summer vacation periods, when [young people] are not enrolled in school" (p. 3). This summer "backsliding" has greater negative impacts on low-income youth and their longer-term reading achievement than on other youth. Hayes \& Grether (1983) reported that summer reading loss accounts for "upwards of 80 percent of the achievement difference" between schools serving high- and low-socioeconomic status (SES) populations (p. 64). Longitudinal, comparative research by Alexander, Entwisle, and Olson (2007) on high-SES and low-SES children's reading achievement at grades 1, 6, and 9 found summer reading loss among the low SES children continued to explain virtually all of the differences in reading achievement between children from high and low-income families.

A meta-analysis of empirical studies on the differential impact of summer vacation periods on more-and less-advantaged students' reading achievement by Cooper, Nye, Charlton, Lindsay, and Greathouse (1996) reported that middle class students' reading proficiency improved modestly in the summer while the proficiency of students from lower-income families declined. According to Cooper et al. (1996), summer vacations create, on average, an annual achievement gap of about 3 months between rich and poor students, favoring the students from highSES backgrounds. This three-month annual gap accumulates to a year and a half achievement gap between the beginning of first grade and the end of sixth grade 
(over five summers). As Allington \& McGill Franzen (2013) explain, "When this accumulating reading achievement gap is combined with an initial achievement gap (at the beginning of schooling), students from low SES families often find themselves 2 or 3 years behind their more advantaged peers as they head to middle schooleven when they receive effective instruction during the school year" (p. 5).

The various available data on summer reading loss consistently portray that it is the most potent explanation for the widening reading-achievement gap between rich and poor children across the elementary and middle school years. In addition, correlational data shows that children who read during the summer months are less likely to experience summer reading setback and more likely to have their achievement remain steady or moderately increase over the school year. As Kim's research (2004) shows, when young people read during the summer, the effects are "potentially large enough to prevent a decline in reading achievement scores from spring to the fall" (p. 169).

\section{Stemming Summer Reading Loss}

Efforts to stem summer reading loss have tended to focus on requiring young people to attend mandatory summer school classes or other remedial reading programs. But these programs can serve to de-motivate young people, as they often focus on test-preparation and/or phonological reading skills and provide few opportunities for authentic reading informed by self text-selection and independent reading levels (Allington \& McGill-Franzen, 2013).

We know that if we want young people to read during the summer monthsand view reading as a life-long, leisure activity — they need access to reading 
materials they want to read, time to read, and instructional support suited to their skill level. The "Book Buddies" program—a university-community partnership between a large, land-grant public university located in the mid-eastern region of the US and a local Boys and Girls club (BGC)—provided these services for six weeks in summer 2014.

\section{The "Book Buddies" Summer Reading Program}

\section{Program Participants}

Youth. Thirteen upper-elementary/middle-school aged youth volunteered to participate in a six-week summer reading program at a local Boys and Girls Club (BCG) located near the university where Susan teaches and Stacey and Allison are doctoral students. Of these 13 youth, nine self-reported as African American when asked to describe their ethnicity, two self-reported as multi-ethnic-White and African-American - and two self-reported as White. The higher number of AfricanAmerican participants reflects the population of members at this particular BGC: $75 \%$ of its members who have attended in the past year are non-white. Six of the participants in the summer reading program were female and seven were male. All participants attended Title I schools prior to the summer reading program, which again is representative of the population of members at this particular BGC: $94 \%$ of the members at this BGC qualify for free or reduced lunch at school.

College students. As a service-learning component attached to Susan's summer young adult literature course-a required course for beginning English teachers enrolled in the secondary education program at the university-ten college students served as "book buddies" to the youth who volunteered to participate in 
the program. Two days a week, for an hour each week, college students traveled to the BGC and met with their book buddies (some book buddy groups were pairsone college student paired to one BGC youth—while other groups consisted of one college student paired with two BGC youth). Prior to the start of the summer program, college students were required to attend an orientation on the BGC program and its philosophy and they received some training on effective reading strategies known to promote reader development and engagement (described in more detail below).

Two days a week, the college students traveled to the BGC to meet with their book buddies. The college students were expected to read what their book buddies chose to read; the book buddy pairs read together for an hour at each session and then talked about what they read. How the book buddy groups read together was decided by the BGC youth. Some youth chose to read aloud to their book buddies, some practiced shared reading, and some wanted their book buddies to read to them. Whether it was in the books they chose or how they read them, the BGC youth retained autonomy.

The college students kept journals on the summer program experience, writing about their growing understandings of young people as readers and themselves as future teachers of reading. They also wrote final reflective papers on the experience. After each book buddy session, the college students met with Susan to debrief the sessions and plan strategies for the next book buddy session. Stacey and Allison also served as research and teaching assistants during the summer program—circulating among the book buddy groups to observe and monitor 
activity, to make suggestions and troubleshoot when needed, and to participate in the groups' daily reading activities.

\section{Program Instructional Tenets}

Access to books and book choice. Research has shown certain practices to be successful in stemming summer reading-loss, including providing access to books young people choose to read when given opportunities to choose. Guthrie and Humenick (2004) evaluated twenty-two studies designed to improve reading outcomes and found four factors that explained most of the variance in motivation and reading achievement. The two largest contributors to reading achievement were access to interesting books and student choice of the books they would read. In addition, Lindsay's (2013) synthesis of reading research noted that studies in which children were given choices of reading material showed substantially larger effects on reading achievement than did studies where children had no choice. But what do young people choose to read when given opportunities to choose?

Research conducted by various reading and adolescent literacy researchers (e.g., Ivey \& Johnston, 2013; Moje, Overby, Tysvaer, \& Morris, 2008; Wilhelm \& Smith, 2014; Williams, 2013; Worthy, Moorman, \& Turner, 1999) provide key insights into what young people choose to read when given opportunities to choose. Findings across this research show that fiction and nonfiction texts that resonate with popular culture and mass media (e.g., books with movie tie-ins; unauthorized biographies about celebrities and sports icons), graphic novels and comic books; humorous/funny books, mysteries/suspense thrillers, supernatural/fantasy books; series fiction; and realistic teen fiction prove to be popular with young people. In 
addition, Hughes-Hassell and Rodge's (2007) study of the leisure reading habits of urban adolescents found that adolescents preferred to read biographies - especially biographies about sports heroes, rap stars, and favorite African American heroes, and "street literature" (e.g., The Coldest Winter Ever, Souljah, 1999). In addition, Cahill et al., (2013) and Allington \& McGill-Franzen (2013) suggest supporting students' text choices with what we know about them (e.g., interests, hobbies, and reading preferences) and what we know about their approximate reading levels. These researchers suggest making titles that represent diverse genres, topics, and reading levels available in reading programs.

We used the available research on young peoples' text preferences and consulted reputable book lists and reviews (e.g., YALSA, Kirkus Reviews), as well as teen choice lists, to select titles for the program. We also regularly added texts to our collection based on participant recommendations and our observations of participants in the program. For example, several participants requested books on LeBron James and Michael Jordan, while another participant specifically requested the Bone graphic novel series. When other participants wanted to read the entire Divergent series and all of the books in the Bluford High series, we obtained both of these series. When we observed another participant carrying one of the Dork Diaries (Russell, 2014) books on a non-program day, we obtained copies of books in that series.

Ultimately, we made a diverse and varied range of texts and text types available to the participants in our summer reading program. At the beginning of the six-week program (and throughout), participants selected titles from roughly 
seventy-five books that represented a wide range of topics, genres, and reading levels. The books were spread out across a large display table that allowed students to explore and skim sample pages. Our participants' most popular text choices can be seen in Table 1.

Effective reading instruction: time to read and time to talk. Finally, we drew on best practices research in reading instruction to support both reader development and reader engagement in the summer reading program. Allington $(2009 ; 2015)$ has long reported that reading volume correlates to developing reading fluency, which aids reading comprehension. Allington offers a simple maxim: "read more, read better" (2015; p. iv). Researchers who describe motivation to read as a bidirectional relationship between "skill and will" (c.f., Morgan \& Fuchs, 2007) seem to support Allington's stance: time to read is crucial to developing the skill that motivates the will. Thus, the "book buddy" pairs spent an hour each day reading the books the youths selected.

Also important to reader development and engagement is the opportunity to discuss books with other readers. As Almasi \& Garas-York (2009) suggest, talk about literature fosters learning, especially higher-order learning. Nystrand's (2006) work in classrooms has shown that discussion centered on authentic questions fosters better and deeper understandings of texts. Cremin, Mottram, Collins, Powell, and Safford (2014) distinguish between "book talk"—-teacher-led talk that can be tied to explicit instructional contexts—and "inside-text talk" —-talk that is more spontaneous and typically child-initiated, and they encourage both forms in classrooms. Littleton and Mercer (2013) further say that both forms 
facilitate "interthinking," or shared understandings and collective meaning-making. Cremin et al., (2014) suggest that talk around and about books encourages the idea that "reading is intrinsically worthy of discussion" and "everyone responding to reading...[is] positioned to achieve success" (p. 98).

Our experience with young readers tells us that when young people are excited about and engaged in what they read, they want to talk about it. The summer reading program provided time to talk by fostering shared reading experiences that gave college and BGC youth similar frames of reference for engaged talk about books.

In addition, because we know reading and writing are complementary processes, and because we know summary writing is a skill strongly related to understanding and long-term learning, we asked the program participants to write daily summaries in their reading journals. Some participants also used their journals to illustrate key events from the books. Other participants composed diary entries from the point of view of the main character, while others opted to write poems and song lyrics. Finally, at the end of each day, BGC youth were asked to add a word, phrase, quotation, drawing, etc. to the "graffiti wall," (Miller, 2013) which hung in the hallway outside the program meeting room.

Intrinsic and extrinsic motivation. Finally, we added a financial incentive-an extrinsic motivator - to motivate adolescents to read during the summer months. Extrinsic motivation, as defined by Wigfield and Guthrie (1997), involves reading for recognition or for grades and competition. 
Intrinsic motivation, by contrast, encompasses a positive self-concept, a desire and tendency to read, and a reported enjoyment of an interest in reading (Sainsbury \& Schagen, 2004). Intrinsically motivated readers read for their own pleasure and satisfaction. Wigfield and Guthrie (1997) identify such aspects of intrinsic motivation as importance, curiosity, involvement, and a preference for challenge.

Studies have found that greater emphasis on extrinsic motivation diminishes students' motivation to read (Guthrie \& Davis, 2003). However, Clark and Rumbold (2006) note that the relationship between intrinsic and extrinsic motivation is not straightforward or a simple "good versus evil" scenario, and indeed, as our research shows, young people may well be motivated by both intrinsic and extrinsic aspects.

The summer program culminated in a book celebration. Participants invited family and friends to enjoy a cookout with their book buddies and be recognized for their reading achievements. Each participant received a superlative certificate and a cash reward for completing the program ( $\$ 10$ USD per book read). The children participated in a group rap of "I Like Big Books and I Cannot Lie" and cheers about reading. Before leaving, they chose a book or a book gift set to take home with them. ${ }^{2}$

\section{The Research}

\section{Theoretical Framework: The Reading Engagement Perspective}

We believe that motivation to read relies on engagement, or the willingness to engage with reading tasks in academic and nonacademic settings. Malloy, Marinak, and Gambrell (2010) explain that "engaged students choose to participate 
in reading tasks and persist in their attempts to make meaning [from texts]..." (p. 2). In contrast to solely cognitive measures of reading motivation, Guthrie and Wigfield (1997) describe the engagement perspective, which can be used as a theoretical framework for adolescent motivation-to-read research. Central to this frame are the motivational constructs of reader self-concept and value.

\section{Reader Self-Concept}

We understand reader self-concept comprises how adolescents perceive themselves as readers, how they think others perceive them as readers, and how well they believe they can accomplish a given task or activity (Bandura, 1977; Eccles, 1983). In addition, we believe a relationship exists between self-concept—as determined by a reader's perceived or expected ability—and motivation to read. As other reading researchers have suggested (cf. Morgan \& Fuchs, 2007; Schunk, 1991), when readers hold negative perceptions about their academic abilities or lack skills necessary for completing academic tasks, they may also lack motivation to engage with such tasks.

\section{Value of Reading}

Strongly related to reader self-concept is reader value, or the "relative attractiveness [an] individual places on a task" (Gambrell, Palmer, Codling, et al., 1996, p. 518). Whether or not adolescents see reading as a valuable pursuit is an important factor in considering their motivation to read. When adolescents perceive reading as valuable and important and have personally relevant reasons for reading, they will read for multiple purposes in multiple settings. Wigfield (1997) suggests reader self-concept works recursively with reading value: when a student 
experiences success with a reading task, the student begins to value reading more highly and thus becomes more intrinsically motivated to read.

\section{Racial and Gender Identity and Reading Motivation}

Tied to reader self-concept and the value a person places on reading is identity. Some researchers argue that racial, ethnic, and gender identities position youth of color by shaping how they view, value, and use literacy practices. David Kirkland $(2011 ; 2013)$ explains that traditional literacy scholarship about young African-American males has tended to rely too heavily on deficit theories, and he warns that researchers and teachers who adopt a deficit perspective fail to understand that reading is an "ideological act" for young African-American males an act tied to identity, to "who they are, what they believe, and who they want others to see them as" (2011, p. 206). Tatum (2008) suggests that African-American adolescent males engage with school-based texts that resemble and help them negotiate their out-of-school contexts and identities.

Still other adolescent reading researchers claim that males will read sports books, "action," "adventure," and/or non-fiction, but we must keep in mind that boys' reading practices are complex and dynamic. Post-structural feminist theories of gender give credence to multiple ways of being male, or "masculinities"(Davies, 1997). This plural form recognizes many forms of masculinity, forms that are constructed in different social, cultural and historical contexts and develop and change over time. As Sciurba (2014-2015) suggests, "such multiplicity needs to be accounted for in discussions of adolescent boys and reading" (p. 309). 
As such, racial and gender identities certainly matter when considering motivation to read. Yet, while researchers have studied minority youths' academic self-efficacy and self-concept beliefs toward school work in general (cf. Gutman \& Midgley, 2000; Unrau \& Schlackman, 2006) and the role of racial identity in academic achievement (cf. Chavous, Bernat, Schmeelk-Cone, et al., 2003), we know little about what motivates African-American adolescent youth to read. While some research on overall academic motivation has been conducted using AfricanAmerican samples (cf. Long, Monoi, Harper, et. al, 2007; Guthrie, Rueda, Gambrell, et al., 2009), little research looks specifically at the voluntary reading motivations of African-American adolescents.

In addition, while important studies have reported on the reading dispositions and book preferences of predominantly White or Latino/a middle school students (e.g., Hughes-Hassell \& Rodge, 2007; Ivey \& Broaddus, 1995; Worthy, Morman, \& Turner, 1999), and African-American primary and elementary students (Campbell, Griswold, \& Smith, 1988; Williams, 2008), few studies have focused explicitly on reader self-concept, value, and reading preferences of AfricanAmerican adolescents in upper grades. ${ }^{3}$ As Williams (2008) explains, "AfricanAmerican participants are an extremely under-represented sample in the literature review of book selection studies," and "a substantial research base does not appear to exist for educators to examine data patterns among children...who are AfricanAmerican and from economically-disadvantaged backgrounds" (p. 52). Our work seeks to address this gap in the research literature.

\section{Methods}


The following research questions guided this study:

- How do African-American middle school-aged adolescents participating in a voluntary summer reading program describe reading and see themselves as readers? (self-concept and value)

- What texts do African-American middle-school-aged adolescents choose to read when given opportunities to choose, and why? (book/genre preferences)

To address these research questions, we employed the Adolescent Motivation to Read Profile (ARMP) developed by Pitcher et al. (2007). Underlying this survey instrument is Guthrie and Wigfield's (1997) definition of motivation as "the beliefs, values, needs, and goals that individuals have" (p. 5). Because motivation to read is multidimensional, we wanted to employ a research instrument that both quantitatively and qualitatively assesses reading motivation. The AMRP is one such public-domain instrument as it employs both a reading survey and a conversational interview. The reading survey consists of 20 items using a four-point scale assessing self-concept as a reader (10 items) and value of reading (10 items).

The conversational interview consists of open-ended questions that encourage free response. The interview questions seek to assess adolescents' reading of a variety of texts, including narrative informational text and general reading, and to ask adolescents about school reading in comparison to home reading. Because we wanted to know how the program participants defined reading and what young adult literature they find relevant, and because we wanted to tie interview questions more closely to the summer reading experience, we modified 
the interview using questions from the original ARMP profile (Pitcher et al., 2007) and from Reeves' (2004) protocol (see our interview protocol in Appendix A). The interview provides for deeper understanding and more authentic insights on students' reading experiences inside and outside school, their attitudes, and motivations.

Because we wanted the college students to familiarize themselves with the Adolescent Motivation to Read survey (and consider using it with their own future students), we had them administer an AMRP survey to their book buddies twice: once at the beginning of the summer program in June 2014 and again at the end of the six-week program in July 2014. Following the guidelines outlined by Pitcher et al (2007), we collected the surveys and scored the survey data. Susan administered the survey again at follow-up meetings with participants in December2014. Stacey and Allison conducted one 30-minute conversational interview with program participants in July 2014, and Susan conducted a more semi-structured interview with each participant in December 2014. The researchers transcribed the interviews and coded them using In Vivo Coding to honor participant voices and to ground analysis from their perspectives (Saldańa, 2013). In addition to the AMRP survey and interviews, data collected included the reflective papers the college students wrote at the end of the summer program as well as field observations of the summer program participants and book buddy sessions conducted by the researchers.

Over the summer and fall of 2014, we spent approximately 50 hours at the BGC and collected data for this study. While we interviewed all of the African- 
American participants in the summer program, this article focuses on three of the males, Tariq, Tyrell, and Tyrone ${ }^{4}$, all of whom had just completed 6th grade when we interviewed them. We focus on these three young people for several reasons: they defined themselves as friends ${ }^{5}$ with similar interests and hobbies, held similar beliefs about the value of reading, and even chose to read similar materials. However, they reflect an important within-group diversity regarding the multiple motivations behind their reading, including the personal relevance they found in the young adult literature they chose to read in the summer reading program.

\section{Survey Results and Interview Findings}

\section{Tariq: “Books Ain't Really My Passion, and Football Is”}

How do African-American middle school-aged adolescents participating in a voluntary summer reading program describe reading and see themselves as readers? (selfconcept and value)

Tariq is a short, stocky, African-American male who wore t-shirts of his favorite basketball players and basketball shorts every day to the summer reading program. When asked to choose adjectives to describe himself by way of introduction in the summer program, Tariq chose "intelligent," "determined," and "popular." Indeed, he proved these descriptions to be true over the course of the program, as he had a constant circle of friends and was supremely confident in his demeanor.

We saw this confidence carry over in his beliefs about himself as a reader. Across the three AMRP surveys administered to Tariq, he averaged a 32.5/40, or $81 \%$ on self-concept. He described himself as a "good reader," using the fact that he 
was in advanced classes at school as evidence of his ability. Tariq's college book buddy —Amy—confirmed his confidence and ability as a reader, writing in her final reflective paper that "Tariq was a very confident reader and jumped at the opportunity to read. He rarely stumbled over words and could usually figure out the words he didn't know. He could also tell me everything he has read almost every time." Amy also wrote about feeling the need to "challenge" Tariq with increasingly difficult texts, because he was reading at a high ability level.

While Tariq expressed confidence and high self-concept as a reader, he expressed a lower value for reading, reflected in his survey score-26/40 or $65 \%$. In an interview, Tariq expressed that reading was important because "Most jobs contain reading...if you can't read, you won't be able to get a good job." Tariq-who thought he might want to play football as an adult (or be a fashion designer-his "fallback plan")—said he expected to "spend a lot of time reading" as an adult because "you've got to be able to read the playbook." Thus, Tariq saw the value in reading in predominantly utilitarian ways.

Ultimately, it seemed, Tariq viewed reading—and people who read frequently—as "boring." He said, “They don't want to do anything." Tariq furthered that reading didn't compare to playing football. Tariq said, "I sometimes like to read. I'll take the time to open a book. But it's hard to stay focused on something for a long time. I can only stay focused 30-45 minutes, then I start looking somewhere else. I can't focus like I can with football. Books ain't really my passion, and football is." Indeed Tariq, like many boys his age, loved sports and excelled at them. He had been playing football on a community league for several years-at both the 
running back and linebacker positions-and had just been selected to play on the BGC basketball team. This love of sports carried over to his reading habits when he got to choose his reading materials, and as we show, Tariq seemed to value reading more-and thus spend more time doing it—when the books were sports-related.

What texts do African-American middle-school aged adolescents choose to read when given opportunities to choose, and why? (book/genre preferences)

The first books Tariq chose to read in the summer program were nonfiction books about NBA basketball players. Tariq first read 2014 Basketball Superstars (NBA) (Kelley, 2014), a book about 14 different NBA players and their rise to stardom, and LeBron James: Basketball Superstar (Mattern, 2011), an unauthorized biography for young readers that provided an intimate look into the life of the basketball star. Tariq had several LeBron t-shirts that he wore to the summer program.

In addition to books about basketball players, Tariq read books at home, outside school, by his favorite author, Mike Lupica. Lupica, a former writer for Sports Illustrated, is a popular author of sports novels for young adults. Tariq said, "Lupica is one of the best football authors, or sports authors anyway." He said, "I relate to sports books. I stay more focused when reading sports books, because I'm more entertained."

When asked how he found books like those written by Lupica, he said that his Dad found them at the library and read them and then encouraged him to read 
them. When asked if he ever took books to school he said, "I just read at home. There's no time to read at school."

But sports books weren't the only books Tariq liked and read on his own. In interviews, Tariq mentioned reading and liking the Big Nate series (Pierce, 2013). This series of cartoon-style books for young adult readers-similar to Diary of a Wimpy Kid —relates the day-to-day trials and tribulations of Big Nate, a middle school boy who dislikes school being raised by a single dad, his teachers, and his older sister, and has a knack for finding trouble. Tariq explained he liked these books because they're "funny" and "I like how they're set up [with text and pictures]. You can see what they're saying. The pictures mimic the story."

But Tariq may have had other, real-life reasons for liking the books. In one interview, Tariq explained that he liked the Big Nate series because "it's true." When asked to clarify his comments, Tariq responded, "Like how that teacher did me and Tyrone." Tariq went on to explain that he had a "racist teacher" at school, and "all she did was get on African-American people." He elaborated, "It was always AfricanAmerican boys getting kicked out of her class. Tyrone got in trouble for having his phone on his desk, but other kids had their phones out and they didn't get in trouble. We told the principal and it got fixed. I didn't believe racism existed in middle school before I got there, but I do now." Tariq went on to say that the teachers make Big Nate mad, and "sometimes a teacher makes me mad. Those books are real."

In the December interview, Tariq also talked about an important book he had been reading in his language arts class, Christopher Paul Curtis's Bud, Not Buddy. Tariq said he liked this book because "Bud would travel," but, he said, "I didn't like 
how he was treated." He continued, "[Reading books like that] puts me in a mood, a mad mood, the way they used to treat Black people back in the old days." Ultimately, Tariq, a confident, able reader who claimed to "sometimes like to read," was reading a variety of genres—sports nonfiction, longer narrative sports fiction (e.g., Lupica), cartoon books such as Big Nate, and historical teen fiction - inside and outside school. Along the way he made important, personal connections to his own experiences through the books.

\section{Tyrell: “I'm Not Ever Gonna Be Reading”}

How do African-American middle school-aged adolescents participating in a voluntary summer reading program describe reading and see themselves as readers? (selfconcept and value)

Tyrell, who often wore t-shirts and cargo shorts to the summer program, had just completed sixth grade at the time of the summer program and had just won the prestigious BGC "Teen of the Year" award. He was good friends with Tariq. They didn't attend the same middle school, but they played on the same community football league (Tyrell played defensive tackle). Tyrell said about Tariq: “He’s actually like my brother. I'm really close to him. We play football together. I put my body on the line for him on the field, he puts his body on the line for me. You don't gotta say it, we just know. We got each other's backs." Their friendship was evident in the summer reading program, as they both worked with Amy in the book buddy sessions. 
Though Tariq was a confident reader, his friend Tyrell seemed less confident and had few positive things to say about reading. While his self-concept score was similar to Tariq's- $32 / 40$ or $80 \%$ - his value score was lower, $23 / 40$ or $57.5 \%$. In interviews, Tyrell said reading was a "way to spend time when there's really nothing else to do." He added, "You could be doing so many other things besides sitting on a couch and holding a book." When asked if he saw himself reading as an adult, he explained, "I'm not really ever gonna be reading. Like, you're not going to come to my house and see me read. I'm going to be doing something, working out or playing video games, so not a whole lot." Ultimately, Tyrell, like Tariq, seemed to equate reading —or at least, reading what others expected or selected for him to readwith a lack of doing or action. Tyrell said, "We [referring to himself and Tariq] have to be moving."

We wondered if Tyrell's feelings about reading and low value score were related to his lack of self-confidence as a reader, as evidenced in other data we collected. Amy described Tyrell in her paper as being "reluctant to read out loud because he [reads] slower than Tariq." Amy also reflected on Tyrell's answer to the survey question about what his friends might think about him as a reader. Tyrell had answered that his friends might think he was a "good" reader, but not "very good," because his friends "did not mess up on words as often as he did and they read a lot faster than he did."

Amy wondered if Tyrell thought to be a good reader, one had to read quickly. We also wondered if he struggled to comprehend what he read. In the follow-up interview with Tyrell, he explained that when he read by himself, he didn't always 
“know how to put it in my mind." He explained he didn't always picture in his mind what he was reading, nor did he always understand what he read. He said, "I could if I wanted to, but I'm not willing to try it. I don't like practicing at it." When asked if he thought reading was a struggle, he responded, "No. I just only care about sports and video games."

But Tyrell did care about reading because he knew it was important to his mom and stepfather, two very influential people in his life. Tyrell explained, "My mom likes it when I read. I do it for her pretty much. Like I said, I don't sit on the couch and read. But sometimes I do it because I know my mom likes it." In describing his step-father, Tyrell explained he "made a difference in my life," and "he's always stressing education is important."

Tyrell said repeatedly that he likes to "make people happy." Like Tariq, he described himself as "determined." Tyrell said he wanted to make his mom happy, so he would read for her. He also wanted to make his step-father happy, so he was determined to make good grades in school. His real father, whom Tyrell saw occasionally, wanted him to excel in sports. Tyrell wanted to make his real father happy, too, so he said he was determined to "be good at football."

What texts do African-American middle-school-aged adolescents choose to read when given opportunities to choose, and why? (book/genre preferences)

Paired with Tariq and Amy in his book buddy group, Tyrell said he read the sports books (e.g., 2014 Basketball Superstars (NBA); LeBron James: Basketball Superstar) because "I like to make people happy, and I knew Tariq would want to 
read these books." In fact, Tyrell said he liked the summer program because he got to read with Tyrell, and they had lots of common interests and similarities. Tyrell said, "I'd read more if I could read with a friend and I got to read what I want to read." Tyrell also said he liked working with Amy: "She wants you to understand it. I knew that she cared."

But on days when Tariq didn't attend the program—usually when the program conflicted with football or basketball practice or field trips-Tyrell had opportunities to choose other reading material, such as Tupac Shakur's (2009) The Rose that Grew from Concrete. Tyrell had an interest in rap music and said in an interview, "I like to rap, but I don't have any beats. I like to read about how to make my own music, how to make it sound cool."

Shakur's book resonated with Tyrell in other ways. Tyrell explained, "I liked reading that book. Tupac went through a lot of things. And what he thought about was occupying himself in his poetry-it's how he got through the day. It was pretty cool to read about what helps him not get so angry." Tyrell also read a children's book called When the Beat Was Born: DJ Kool Herc and the Creation of Hip Hop (Hill \& Taylor, 2013).

In her reflective paper, Amy wrote that Tyrell was a "bright and eager" reader when they were reading the books about rap music and artists. Amy wrote: “Tyrell enjoyed seeing how Tupac felt and always tried to figure out why he wrote the poems he did. When we read the poems, Tyrell really focused on the wording of the poems and hidden meanings." 
Amy also explained that when they were collaboratively reading the Tupac poems, Tyrell "opened up to me about his parents." In one of Tupac's poems, he writes about a relationship with a light-skinned woman. Tyrell was light-skinned, and he explained to Amy that his mother was white and his real father black. He told Amy about times when he had heard other Black men tell his father that he did not need to be with a white woman, and he talked about how these words had made him angry. Amy thought reading about Tupac's experiences might have helped Tyrell make some real-life connections and navigate his own emotions. Amy said that the Tupac book inspired Tyrell to write a rap song in his journal. In his song, Tyrell expressed gratitude for Tupac's writings and for the fact that he had not experienced all that Tupac had.

\section{Tyrone: “I Connect With That"}

How do African-American middle school-aged male adolescents participating in a voluntary summer reading program describe reading and see themselves as readers? (self-concept and value)

Like Tariq, Tyrone-a lighter-skinned African-American male who wore his hair in braids during the summer-wore basketball jerseys, shorts, and sneakers every day to the summer reading program. Tyrone and Tariq were good friends and had just completed the $6^{\text {th }}$ grade at the same middle school, where they were in some of the same advanced classes. When asked to choose adjectives to describe himself by way of introduction in the summer program, Tyrone chose "awesome," "likeable," and "X-factor," exuding a confidence similar to Tariq's. 
This confidence carried over to Tyrone's beliefs about himself as a reader. Across the three AMRP surveys administered to Tyrone, he averaged a 32/40, or $80 \%$ on self-concept. Like Tariq, he described himself as a "good reader," using the fact that he was in advanced classes at school as evidence. In the second interview Susan conducted with Tyrone in December, when Tyrone was in $7^{\text {th }}$ grade, he explained he was a good reader "because I can, I have a good vocabulary for a $7^{\text {th }}$ grader. Yesterday, I was the only person to get 100 on my vocabulary test. “

Tyrone's college reading buddy, Kevin, confirmed Tyrone's ability as a reader. Kevin wrote in his reflective paper, "Tyrone is a very bright kid and he was a very good reader. He rarely mispronounced words, and his vocabulary was wellrounded for his age."

Tyrone also seemed to value reading (he had the highest value score of the three participants), but like Tariq, not too highly, scoring $28 / 40$ or $70 \%$. When asked if he felt knowing how to read well was important, he replied that it was “because say you're trying to fill out a job application for a job, if you don't know what the words are, it's going to be hard." Like Tariq, Tyrone seemed to see a future, utilitarian purpose for reading rather than a personal purpose. In the second interview, Tyrone described two people who influenced him to read. He said his older brother, a college student, read frequently, and he also mentioned an older sister in high school. Tyrone then talked about his dad: “My dad—he's not really good at reading or writing. He wishes he had learned how to read and write better." When asked if Tyrone maybe felt that reading was important because of his dad, he said yes. 
We thought it interesting to note that Tyrone's predominant answer to most interview questions about reading was "sometimes." Did he like to read? “Sometimes." Did he like getting books as presents? "Sometimes.” Was reading fun? "Sometimes." We came to learn that only when Tyrone could read sports-related books—specifically those about basketball and his favorite basketball players, LeBron James and Michael Jordan—was reading something he "sometimes" liked to do.

What texts do African-American middle-school-aged adolescents choose to read when given opportunities to choose? (book/genre preferences)

Every single book Tyrone chose to read concerned basketball. Like Tariq and Tyrell, Tyrone read 2014 Basketball Superstars (NBA) (Kelley, 2014) and LeBron James: Basketball Superstar (Mattern, 2011). Tyrone also read Michael Jordan: Life Above the Rim, a biography by former sports journalist and young-adult novelist Robert Lipsyte. When asked why Tyrone liked reading about LeBron James, he explained, "To me, he's a real good player and he does all these organizations for these kids that aren't able to play basketball because of money." When asked how he knew about James' charitable work, Tyrone explained that he also watched YouTube documentaries about LeBron James at home. Tyrone explained he liked Michael Jordan because "he's a legend, one of the greatest to ever play the game."

Tyrone seemed to have a respect for the game of basketball and for the greats who played it. And while Tyrone played basketball at the BGC and shared facts and figures about LeBron and Michael Jordan with Tariq and Tyrell, Tyrone 
said he didn't aspire to be a basketball superstar. Instead, he wanted to be an engineer. Unlike Tariq, who seemed to look at the sports-related books as mirror images of himself, Tyrone seemed to read the books for different reasons. Tyrone explained, “When LeBron was younger, he wasn't really like, I don't know how to put it, but he wasn't that good at basketball. As he got older he got better. The more he practiced, the better he got. So I connect with that."

The importance of these sports books for Tyrone seemed to be in the messages he took from them: diligence, practice, perseverance. Kevin, Tyrone's college buddy seemed, also saw Tyrone's reasons for reading the sports books. In his reflective paper, Kevin wrote, "I think Tyrone was more interested in reading about successful people than basketball. The Michael Jordan book centered around the problems Michael faced growing up, and not so much on the actual action of playing basketball. Tyrone was interested in the basketball, but he seemed more interested in what the players did off the court, for example he was interested in Michael's home-life and upbringing. Tyrone wanted to read about people who looked like him and had a similar background as him, and were a product of themselves. These players did not ask for help from anyone, they did it all on their own. That's what was attractive to Tyrone."

We also wondered how much a social role played in Tyrone's text choices. In the December interview with Susan, he explained, "I used to think that reading could not be cool. When I got into middle school, the teacher said we were going to be going to the library often. So I just got books about basketball or get books about engineering. You don't have to be not cool to read." Kevin also mentioned in his 
reflective paper that while Tyrone seemed more interested in the background and life stories of the basketball players he read about, he only observed Tyrone sharing player statistics with his friends.

We also wondered if Tyrone's choice of reading materials was related to his need to feel or appear competent to others. Smith and Wilhelm (2002) describe the need to feel competent as a motivating factor in the literate lives of adolescent boys. Tyrone was the only participant of the three to say he worried what others thought about his reading ability. He said, "I get nervous when I'm reading out loud because I'm afraid I am going to trip up on a word. That can be embarrassing sometimes. I get nervous, nervous about other kids not thinking I'm a good reader." Perhaps the sports-related books Tyrone chose to read-as socially sanctioned reading materials among his friends-made him appear to be a socially, if not academically, competent reader (although he was a competent reader, too).

Tyrone's desire to appear competent might have also driven his competitiveness. Kevin described Tyrone as "competitive": "Tyrone wants his peers to think highly of him. He wants to be better than his peers in everything from basketball to reading. Competition seems to be one of the greatest motivators for Tyrone, as he is able to compete against his peers in order to show them he is intelligent." Kevin later wrote in his reflective paper that Tyrone confided in him that the reason he was doing the summer reading program was for the money. Indeed, Tyrone did read the most books of any participant in the program—ten in all-winning $\$ 100$ at the culminating book celebration. Tyrone was very pleased 
with himself and told us he planned to use the money to buy new school clothes and school supplies for himself.

\section{Implications and Significance}

\section{Multiple Motivations to Read}

Social motivations. Smith and Wilhelm's (2002) literacy research with adolescent boys revealed how social relationships matter to boys. Reading about sports might have enabled Tariq, Tyrell, and Tyrone to be literate in sociallyacceptable ways with each other. Tariq explained how he could talk to Tyrell and Tyrone at the BGC and school about the sports books he read because "they read them, too." For Tyrell, reading the sports-related books seemed to be driven completely by his desire to make his friend Tariq happy.

But we also saw other social motivating forces in these young males' lives. Tariq's father seemed to play an important role in developing his son's beliefs about reading, and he supported his son's love for sports-related materials by finding and sharing books with him. Tyrell's family members seemed to be motivating forces in his burgeoning literate life, as Tyrell knew that reading and taking his education seriously was important to his mother and step-father. And Tyrone's father and brother seemed to be motivating forces, albeit indirect ones, in Tyrone's beliefs about the importance of reading.

González (1997) has described "literacy agents" as family members, teachers, and other adults who get young people to engage with literature, and we believe our work points to the need to more carefully consider the social role(s) such "agents" play in young peoples' motivation to read. 
Personally relevant motivations. Guthrie and Humenick (2004) have reported that the two largest contributions to reading motivation and achievement are access to interesting books and student choice of the books. But what books are "interesting" to young readers like Tariq, Tyrell, and Tyrone, and why? Why do these young men choose some books and not others?

Books about sports icons and heroes are interesting to Tariq, Tyrell, and Tyrone, and this confirms research that tells us adolescent males like to read sports books (Hughes-Hassel and Rodge's, 2007; Newkirk, 2002). But there were some interesting nuances in the ways each of the boys connected to or found relevance in the sports-related texts, and Tariq and Tyrell read other genres besides sports books.

Kirkland (2011) likens the books young African-American males read to the clothes they wear, to an "extension of self. " Kirkland explains, “...think of reading as something greater than a mere literate act, but as a 'lens on the self"'(p. 206). Tariq made very clear each day in the summer program what was important to him. His LeBron James t-shirts, like the sports books he chose to read, communicated a message: I am a serious athlete and expect to be seen as one. Tariq loved sports and wanted to excel at them—-he wanted to be a professional football player-and he found books about sports relevant because they enabled him to immerse himself in a topic he knew and about which he wanted to learn more. As Tariq said, reading about sports "entertained" him and kept him "focused" on the reading, and as Amy, his college buddy, wrote in her reflective paper: "Tariq wanted to learn more about the professionals who played the game." 
For Tariq, the sports-related books seemed to serve as a mirror imageconfirming and validating his identity as an athlete- but so did other books Tariq found relevant, such as Big Nate and Bud, Not Buddy. Tariq connected to these books through the personal and historical experiences of racism. He saw his own experiences with racism—and experiences of other African-Americans—reflected in these books, and perhaps he felt these books confirmed some of what he was feeling. As Tariq expressed, these books "are real."

The sports-related books were relevant to Tyrell because they made his friend Tariq happy. Tyrell didn't talk about seeing himself as an athlete in the books, nor did he look to the books to improve his skills. Instead, the books satisfied Tyrell's social and relational needs: he read them because his friend read them.

Smith and Wilhelm's (2002) research on adolescent boys' literacies suggests that boys prefer "exportable" books, ones that can easily be "exported into conversation" (p. 152), and books that contribute to social networks with friends and family members. We see these social connections to texts play out to some degree for all the boys, who shared statistics and facts about the sports icons with each other. In fact, many of the boys' contributions to the program's graffiti wall were often phrases and vocabulary words (e.g., "King James," "Like Mike," "rimshots") lifted from the sports-related books they read. Tariq and Tyrell's college buddy, Amy, wrote in her paper that a lot of the talk in her sessions with Tariq and Tyrell centered on which basketball player Tariq and Tyrell thought was better. When Tyrell read Tupac Shakur's book, he started making more personal connections with literature. Like Tariq, who saw himself in the sports books he read, 
Tyrell seemed to see himself-and his anger-reflected in the Tupac text. And like Tariq, who may have looked to the sports books to validate his identity and to improve his game, Tyrell seemed to look to Tupac's poetry to learn how to navigate his own emotions.

Ultimately, it seemed to us that Tyrell was just beginning to find himself as a reader in the summer program. He differed from the confident, self-assured reader Tariq, who knew he would find himself in the books he chose to read. In contrast, Tyrell didn't seem to know what texts would be relevant to him, and he relied on Tariq and Amy to help him find texts to connect to. We wonder how Tyrell might feel about reading — and himself as a reader-if he had more opportunities to find himself and explore his emotions through texts he deemed relevant.

Tyrone didn't necessarily look to sports books to learn how to play the game or because he aspired to be a great basketball star. Instead, Tyrone seemed to read the sports books for the life messages they imparted. Tyrone didn't see himself as the next great basketball player, but he did see himself as being successful in life. He looked to books about underdog sports heroes like LeBron James and Michael Jordan to show him the way.

\section{Mirrors and Maps?}

In a 2014 New York Times article, Christopher Myers, son of Walter Dean Myers and an award-winning children's book illustrator, suggests that young people perceive books less as mirrors and more as road maps for life. He writes, "[Young people] are indeed searching for their place in the world, but they are also deciding 
where they want to go. They create, through the stories they're given, an atlas of their world, of their relationships to others, of their possible destinations."

Myers goes on to criticize the dearth of young African-American characters in popular contemporary fiction for youth—and thus the dearth of diverse, creative, and imaginative landscapes for youth of color - and suggests this lack could adversely affect youth of color.

For example, Myers tells a story of a young boy who dreams of becoming an NBA superstar and a rap superstar because these are the only roadmaps available to him:

Looking at him, I think that these are not necessarily his dreams; they are just the dreams that have been offered him, the places he can go in the narrow geography that has been delineated for him, strung along in a surreal and improbable sequence. As much as I hope that I'm wrong, that in several years the Brooklyn Nets sign a 5-foot-8 point guard with amazing flow, who raps and hoops in the same arenas, I think it's necessary to provide for boys and girls like him a more expansive landscape upon which to dream. (C. Myers, 2014)

We agree that youth of color need more expansive landscapes upon which to dream than currently available, and we like the idea that young people look to books as roadmaps for life and not always (or solely) as mirrors. But we do push back a little on disagree with the idea that stories about basketball and rap superstars are too "narrow" and "flawed" (to use Myers' words) for youth of color, especially African-American adolescent males. 
As Tariq, Tyrell, and Tyrone's experiences in the "Book Buddy" summer reading program suggest, textual relevance-and thus motivation to read-has many faces. Tariq wanted to "see" himself in texts, and the images he saw reflected back at him were usually pretty accurate. For Tyrell, the image seemed less clear, if he could see an image at all. His words about not being to visualize when he reads"I don't always know how to put it in my mind"-makes us wonder if looking to books as a mirror is something he expects from the reading experience or even understands. Tyrell seemed to have that "ah-ha" moment with the Tupac book, but he also seemed to search the text for meanings he could apply to his own life. Similarly, Tyrone didn't need to see a mirrored self in the young adult literature he read, but he did want to see a roadmap for success. He was equally interested in his sports heroes' hard work and their current stats and figures. Ultimately, the sports books connected Tyrone to his friends, gave him a sense of competence, and gave him hope for his future success.

\section{Connecting Relevance and Reading Value in Motivation to Read}

In addition, we are intrigued (but not surprised) by the contradictions we see among the participants' value scores on the AMR, their stated ambivalence about reading, and their actual reading behavior in the summer reading program. All of the boys placed a lower value on reading than self-concept and talked about reading in unenthusiastic ways ("it's boring," "I read when I have to"), yet they were avid, engaged readers (or willing to be engaged, in the case of Tyrell) in the summer reading program. Tariq was committed to reading a variety of books about sports in the program because they validated and confirmed his identity as an athlete, but 
Tariq also read other genres of his own accord, outside school during the school year. Tyrell was interested in the sports-related books, but he also connected with the poetry in Tupac Shakur's The Rose that Grew from Concrete. Tyrone was also committed to reading as many sports-related books as he could, though he read these books for a variety of reasons: he liked the affirming messages he found in them and the statistics and facts he could share with his friends, and he wanted to win the most money to buy school supplies and clothes.

Yet Tariq and Tyrone described the value of reading in utilitarian ways, as a way to "get a job" in the future, and Tyrell valued reading because he knew it made his parents happy. We wonder, then, if we need to do more in classrooms and in summer reading programs like ours to help young readers consider the powerful connections that can occur between a reader and a text—connections that highlight personal relevance and purposes for reading. Perhaps if we emphasized these goals, young readers would come to value reading differently, in more personally relevant ways, and to see reading as gratifying and meaningful.

\section{Let Them Read Sports Books}

Finally, our work with Tariq, Tyrell, and Tyrone has us wondering what a reading program in schools tailored to the multiple reasons and motivations boys seek out sports-related young adult literature would look like. We know choice is important, as it imparts feelings of ownership, competence, and control that are motivating factors in boys' literacy practices (Smith \& Wilhelm, 2002). We also know from Fisher \& Frey's (2012) work with middle school boys that an inquirydriven curriculum—guided by essential questions and incorporating 
interdisciplinary knowledge—can motivate boys to engage in reading tasks. Fisher and Frey (2012) suggest using thought-provoking questions "as a practical means for organizing curriculum around issues of importance to adolescents" (p. 592).

We can't help but think about how boys like Tariq, Tyrell, and Tyrone might respond to curriculum centered around sports-related inquiry and "thoughtprovoking questions" about the world of professional basketball and football. As Kevin wrote in his reflective paper about Tyrone, Tyrone was interested in the biography about Michael Jordan because "the book dove straight-forward into the politics of the sports, including race relations." How might boys respond to curriculum that welcomes their expertise, knowledge, and passion, and encourages them to build on what they know through critical thinking?

Ultimately, we feel our work leaves us with more important questions than answers, and we feel we still have much to learn from young people. We must always be willing to listen—and act on—what they have to tell us about the young adult literature they choose to read, and we must consider their multiple motivations for reading. 


\section{Footnotes}

1Pseudonyms used throughout.

${ }^{2}$ Research indicates a relationship between book ownership and reading attainment: young people who have books of their own are more likely to report daily reading, whereas those without books of their own are more likely to say they never read (Evans, Kelley, Sikora, \& Treiman, 2010; Lindsay, 2010)

3For studies examining African-American youths' experiences reading "street” or "urban street fiction, " see Gibson, 2010; Guerra, 2012; Marshall, Staples, \& Gibson, 2009.

4 Tariq identified as African-American, and Tyrell and Tyrone both identified as White and African-American.

${ }^{5}$ Both Tyrell and Tyrone claimed to be close friends with Tariq, but Tyrell and Tyrone described themselves more as "acquaintances" with each other. 


\section{References}

Alexander, K.L., Entwisle, D.R., \& Olson, L.S. (2007). Lasting consequences of the summer learning gap. American Sociological Review, 72(2), 167-180.

Allington, R.L., (2015). What really matters for middle school readers: From research to practice. New York: Pearson.

Allington, R.L. (2009). What really matters in fluency: Research-based practices across the curriculum. New York: Pearson.

Allington, R.L. \& McGill-Franzen, A. (Eds.) (2013). Summer reading: Closing the rich/poor reading achievement gap. New York, NY: Teachers College Press.

Almasi, J.F., \& Gara-York, K. (2009). Comprehension and peer discussion. In S. Israel \& G.G. Duffy (Eds.), Handbook of research on reading comprehension. (pp. 470-493). Mahwah, NJ: Erlbaum.

Bandura, A. (1977). Self-efficacy: Toward a unifying theory of behavioral change. Psychological Review, 84, 191-215.

Blasingame, J. (2007). Books that don't bore 'em. New York: Scholastic.

Cahill, C., Horvath, K., McGill-Franzen, A., \& Allington, R. (2013). No more summer reading loss. Portsmouth, NH: Heinemann.

Campbell, K., Griswold, D., \& Smith, F. (1988). Effects of trade back covers (hardback or paperback) on individualized reading choices by elementary-age children. Reading Improvement, 25, 166-178.

Chavous, T.M., Bernat, D.H., Schmeelk-Cone, K., Caldwell, C.H. et al. (2003). Racial identity and academic attainment among African American adolescents. Child Development, 74(4), 1076-1090. 
Clark, C., and Rumbold, K. (2006). Reading for pleasure: A research overview. London: National Literacy Trust.

Connell, R.W. (1995) Masculinities. Berkeley and Los Angeles, CA: University of California Press.

Cooper, H., Nye, B., Charlton, K., Lindsay, J., \& Greathouse, S. (1996). The effects of summer vacation on achievement test scores: A narrative and meta-analytic review. Review of Educational Research, 66, 227-268.

Cremin, T., Mottram, M., Collins, F.M., Powell, S., \& Safford, K. (2014). Building communities of engaged readers: Reading for pleasure. New York, NY: Routledge.

Davies, B. (1997) Constructing and deconstructing masculinities through critical literacy. Gender and Education,9(1), pp. 9-30.

Eccles, J.S. (1983). Expectancies, values, and academic behaviors. In J.T. Spence (Ed.), Achievement and achievement motives: Psychological and sociological approaches (pp. 75-114). San Francisco: W.H. Freeman.

Evans, M.D.R., Kelley, J., Sikora, J., \& Treiman, D.J. (2010). Family scholarly culture and educational success: Books and schooling in 27 nations. Research in Social Stratification and Mobility, 28, 171-197.

Gambrell L.B., Palmer, B.M., Codling, R.M., et al. (1996). Assessing motivation to read. The Reading Teacher, 49(7), 519-533.

Gibson, S. (2010). Critical readings: African American girls and urban fiction. Journal of Adolescent and Adult Literacy, 53(7), 565-574. 
González, N.L. (1997). Nancy Drew: Girls' literature, women's reading groups, and the transmission of literacy. Journal of Literacy Research, 29(2), 221-251.

Guerra, S.F. (2012). Using urban fiction to engage at-risk and incarcerated youths in literacy instruction. Journal of Adolescent and Adult Literacy, 55(5), 385-394.

Guthrie, J.T., Coddington, C.S., \& Wigfield, A. (2009). Profiles of reading motivation among African American and Caucasian students. Journal of Literacy Research, 41, 317-353.

Guthrie, J. T., \& Davis, M.H. (2003). Motivating struggling readers in middle school through an engagement model of classroom practice. Reading and Writing Quarterly, 59(5), 414-424.

Guthrie, J.T., \& Humenick, N. (2004). Motivating students to read: Evidence for classroom practices that increase reading motivation and achievement. In P. McCardle \& V. Chhabra (Eds.), The voice of evidence in reading research (pp. 329-354). Baltimore, MD: Brookes.

Guthrie, J.T., Rueda, R., Gambrell, L.B., et al. (2009). Roles of engagement, valuing, and identification in reading development of students from diverse backgrounds. In L.M. Morrow, R. Rueda, \& D. Lapp (Eds.), Handbook of research on literacy and diversity (pp. 195-215). New York: The Guilford Press.

Gutman, L.L., \& Midgley, C. (2000). The role of protective factors in supporting academic achievement of poor African American students during the middle school transition. Journal of Youth and Adolescence, 29(2), 223-248. 
Hayes, D.P., \& Grether, J. (1983). The school year and vacations: When do students learn? Cornell Journal of School Relations, 17, 56-71.

Hughes-Hassell, S., \& Rodge, P. (2007). The leisure reading habits of urban adolescents. Journal of Adolescent and Adult Literacy, 51(1), 22-33.

Ivey, G., \& Broaddus, K. (1995). "Just plain reading:" A survey of what makes students want to read in middle school classrooms. Reading Research Quarterly, 36(4), 350-377.

Ivey, G., \& Johnston, P.H. (2013). Engagement with young adult literature: Outcomes and processes. Reading Research Quarterly, 48(3), 255-275.

Kim, J. (2004). Summer reading and the ethnic achievement gap. Journal of Education of Students at Risk, 9, (2), 169-189.

Kirkland, D.E. (2013). A search past silence: The literacy of young African-American men. New York, NY: Teachers College Press.

Kirkland, D.E. (2011). Books like clothes: Engaging young African-American men with reading. Journal of Adolescent and Adult Literacy, 55(3), 199-208.

Lesesne, T. (2003). Making the match: The right book for the right reader at the right time. Portland, ME: Stenhouse.

Lindsay, J. (2013). Interventions that increase children's access to print material and improve their reading proficiencies. In R. Allington \& A. McGill-Franzen (Eds.), Summer reading: Closing the rich/poor reading achievement gap (pp. 20-38). New York, NY: Teachers College Press. 
Lindsay, J. (2010). Children's access to print material and education-related outcomes: Findings from a meta-analytic review. Naperville, IL: Learning Point Associates.

Littleton, K., \& Mercer, N. (2013). Interthinking: Putting talk to work. London: Routledge.

Long, J.F., Monoi, S., Harper, B., Knoblauch, D., \& Murphy, P. K. (2007). Academic motivation and achievement among urban adolescents. Urban Education, 42(3), 196-222.

Malloy, J.A., Marinak, B.A., \& Gambrell, L.B. (2010). We hope you dance: Creating a community of literate souls [Introduction]. In J.A. Malloy, B.A. Marinak, \& L.B. Gambrell (Eds.), Essential readings on motivation. Newark, DE: International Reading Association.

Marshall, E., Staples, J., \& Gibson, S. (2009). Ghetto fabulous: Reading black adolescent femininity in comtemporary urban street fiction. Journal of Adolescent and Adult Literacy, 53(1), 28-36.

Mazzoni, S., Gambrell, L.B., \& Korkeamaki, R. (1999). A cross-cultural perspective of early literacy motivation. Reading Psychology, 20, 237-253.

Miller, D. (2013). Reading in the wild: The book whisperers' keys to cultivating lifelong reading habits. Jossey-Bass.

Moje, E., Overby, M., Tysvaer, N., \& Morris, K. (2008). The complex world of adolescent literacy: Myths, motivations, and mysteries. Harvard Educational Review, 78(1), 1-35. 
Morgan, P. L., \& Fuchs, D. (2007). Is there a bidirectional relationship between children's reading skills and reading motivation? Exceptional Children, 73(2), 165-184.

Myers, C. (2014, March 15). The apartheid of children's literature. The New York Times. Retrieved from http://www.nytimes.com/2014/03/16/opinion/sunday/the-apartheid-ofchildrens-literature.html

Nilsen, A.P., \& Donelson, K.L. (2009). Literature for today's young adults. (8 ${ }^{\text {th }}$ edition.) New York: Pearson.

Newkirk, T. (2002). Misreading masculinity: Boys, literacy and popular culture. Portsmouth, NH: Heinemann.

Nystrand, M. (2006). Research on the role of classroom discourse as it affects reading comprehension. Research in the Teaching of English, 40, 392-412.

Pitcher, S.M., Albright, L.K., DeLaney, C.J. et al. (2007). Assessing adolescents' motivation to read. Journal of Adolescent and Adult Literacy, 50(5), 378-396.

Reeves, A. (2004). Adolescents talk about reading: Exploring resistance to and engagement with text. Newark, DE: International Reading Association.

Sainsbury, M., \& Schagen, I. (2004). Attitudes towards reading at ages nine and eleven. Journal of Research in Reading, 27(4), 387-400.

Saldańa, J. (2013). The coding manual for qualitative researchers. ( $2^{\text {nd }}$ edition). New York: Sage.

Schunk, D.H. (1991). Self-efficacy and academic motivation. Educational Psychologist, 26, 233-262. 
Sciurba, K. (2014-2015). Texts as mirrors, texts as windows. Journal of Adolescent and Adult Literacy, 58(4), 308-316.

Smith, M., \& Wilhelm, J. (2002). Reading don't fix no chevys": Literacy in the lives of young men. Portsmouth, NH: Heinemann.

Tatum, A. W. (2008). Toward a more anatomically complete model of literacy instruction: A focus on African American male adolescents and texts. Harvard Educational Review, 78(1), 155-180.

Unrau, M., \& Schlackman, J. (2006). Motivation and its relationship with reading achievement in an urban middle school. Journal of Educational Research, 100(2), 81-101.

Wigfield, A. (1997). Children's motivations for reading and reading engagement. In J.T. Guthrie \& A. Wigfield (Eds.), Reading engagement: Motivating readers through integrated instruction (pp. 14-33). Newark, DE: International Reading Association.

Wigfield, A., \& Guthrie, J.T. (1997). Relations of children's motivation for reading to the amount and breadth of reading. Journal of Educational Psychology, 89, 420-432.

Wilhelm, J. D. (1997). You gotta be the book": Teaching engaged and reflective reading with adolescents. New York: Teachers College Press.

Wilhelm, J., \& Smith, M. (2014). Reading unbound: Why kids need to read what they want and why we should let them. New York: Scholastic.

Williams, L.M. (2013). The importance of book selections: Enticing struggling readers to say 'I want to read that one!' In R. Allington \& A. McGill-Franzen 
(Eds.), Summer reading: Closing the rich/poor reading achievement gap (pp. 55-69). New York, NY: Teachers College Press.

Williams, L. M. (2008). Book selections of economically disadvantaged AfricanAmerican elementary students. Journal of Educational Research, 102(1), 5163.

Worthy, J., Moorman, M., \& Turner, M. (1999). What Johnny likes to read is hard to find in schools. Reading Research Quarterly, 34(1), 12-27. 


\section{APPENDIX A}

Interview Protocol for Reading Engagement \& Motivation Study

\section{Background}

1. Pseudonym, age

2. Grade going into in school, what school going into, what school just finished

Reading Dispositions

1. What comes to mind when I say reading?

2. Did you read anything at home yesterday? What?

3. What is your favorite kind of reading? What gets you excited to read? Why?

4. Do you have a favorite author/favorite genre?

5. What did you read recently that you really enjoyed?

6. Where do you find books/reading materials that you like?

7. Is there anything right now that you want to read? How did you learn about it?

8. What is the worst kind of reading for you? Why?

Reading Socially

1. Do you ever read with friends or other people? If so, what do you read? How does that go?

2. Do you have friends who read more than you do? Less than you do?

3. CHECK SURVEY DATA FOR QUESTIONS ABOUT FRIENDS' PERCEPTIONS OF INTERVIEWEE AS READER: \#1, 3, 4, 6, 11. How did interviewee answer these questions? Ask interviewee to elaborate on survey responses.

4. Do members of your family read at home? (Reading can mean newspapers, magazines, etc.)

5. Do you share reading materials with members of your family? If so, what? How does this go?

6. Can you remember family members (someone) reading to you when you were little? What do you remember?

Reading at School

1. Walk me through an ordinary school day last year and tell me where you did any reading. What kinds of reading do you remember doing at school?

2. In what class do you most like to read? Why?

3. In what class is the reading most difficult? Why?

4. Have any of your teachers done something with reading that you really enjoyed? Explain. Why did you enjoy it?

5. How do you think (your) teachers feel about reading?

6. Tell me about reading assignments you get (assignments in school, HW). 
7. Do you ever feel like you need help with reading? What kind of help would be useful?

8. Do you get help?

9. What do teachers do that helps students become good readers? What do you wish teachers would do?

10. CHECK SURVEY DATA FOR QUESTIONS ABOUT READING ALOUD: \# 18, 19. How did interviewee answer these questions? Ask interviewee to elaborate on survey responses.

11. Do you ever get to read what you want to read at school?

12. Do you get time during the school day to read independently?

Future Plans

1. What do you think you'll do when you leave high school?

2. Do you think your future job will involve much reading?

3. Do you see yourself doing much reading in your adult life after you're finished with school?

4. Would you like your children to do a lot of reading?

5. Would you like your children to be good at reading? To enjoy it?

Wrap-Up

1. Have your ideas or feelings about reading changed as you've grown older?

2. We are trying to decide if we should do the "Book Buddy" program next summer. What do you think? Did you enjoy it? Why or why not? What would you change?

3. Did your ideas or feelings about reading change as a result of your participation in the "Book Buddy" program?

4. Last questions: Why should a person read? Why do you read? 


\begin{tabular}{|c|c|}
\hline \multicolumn{2}{|l|}{ Table 1} \\
\hline \multicolumn{2}{|c|}{ Text Types and Titles Popular with Summer Reading Program Participants } \\
\hline Text Types & Text Titles \\
\hline Graphic novels & $\begin{array}{l}\text { *Bone (Smith, 2004); *Diary of a Wimpy } \\
\text { Kid (Kinney, 2007); *Big Nate (Peirce, } \\
\text { 2012); Dork Diaries, (Russell, 2014) }\end{array}$ \\
\hline Sports biographies/nonfiction & $\begin{array}{l}2014 \text { NBA Superstars (Kelley, 2014); } \\
\text { LeBron James: Basketball Superstar } \\
\text { (Mattern, 2011); Michael Jordan: A Life } \\
\text { Above the Rim (Lipsyte, 2010) }\end{array}$ \\
\hline Sports poetry & $\begin{array}{l}\text { Rimshots: Basketball Pix, Rolls, and } \\
\text { Rhythms (Smith, 2000) }\end{array}$ \\
\hline Books with movie tie-ins & *Divergent (Roth, 2011) \\
\hline Series fiction & *Bluford High series (multiple authors) \\
\hline Books about rap music and rap artists & $\begin{array}{l}\text { The Rose that Grew From Concrete } \\
\text { (Shakur, 2009); When the Beat Was } \\
\text { Born: DJ Cool Herc, (Hill \& Taylor, 2013); } \\
\text { *Hip Hop Family Tree, Part } 1 \text { (Piskor, } \\
\text { 2013) }\end{array}$ \\
\hline Young adult urban fiction & $\begin{array}{l}\text { Money Hungry (Flake, 2007); The First } \\
\text { Part Last (Johnson, 2010) }\end{array}$ \\
\hline \multicolumn{2}{|c|}{$\begin{array}{l}\text { Note: We have starred the titles that cross categories. As example, Diary of a Wimpy } \\
\text { Kid can be defined as a graphic novel, but also represents series fiction, as there are } \\
\text { multiple books in this series. We have placed titles in the category that we think best } \\
\text { represents why participants said they liked the book (e.g., "it's got pictures and } \\
\text { words"). }\end{array}$} \\
\hline
\end{tabular}

